\title{
Alpha-1-proteinase inhibitor regulates CD4 lymphocyte levels and is rate limiting in HIV-1 disease
}

\author{
Cynthia L Bristow*, Mariya A Babayeva, Michelle Labrunda, Michael P Mullen, Jose Cortes, Ronald Winston \\ From 17th International Symposium on HIV and Emerging Infectious Diseases (ISHEID) \\ Marseille, France. 23-25 May 2012
}

\section{Introduction}

Adult stem cell migration through human hematopoietic tissue requires the chemokine CXCL12 and its receptor CXCR4. In addition, human leukocyte elastase (HLE) plays a key role. When HLE is located on the cell surface (HLECS), it acts not as a proteinase, but as a receptor for $\alpha 1$ proteinase inhibitor ( $\alpha_{1} \mathrm{PI}, \alpha 1$ antitrypsin). Binding of $\alpha_{1}$ PI to HLECS forms a motogenic complex. We previously demonstrated that $\alpha_{1}$ PI deficiency attends HIV-1 disease. Here we investigate the mechanism and therapeutically address the $\alpha_{1}$ PI deficiency of HIV-1 infection.

\section{Materials and methods}

Blood was collected from 30 HIV-1 uninfected and 39 HIV-1 infected adults. Residual sera was obtained from 20 HIV-1 uninfected chimpanzees, 2 chimpanzees pre- and 42 months post-HIV-1 challenge, 12 HIV-1-immunized macaques, and 3 SHIV-infected macaques. Three HIV-1 infected individuals received $\alpha_{1} \mathrm{PI}$ augmentation therapy.

\section{Results}

In HIV-1 uninfected individuals, $\mathrm{CD} 4^{+}$lymphocytes were correlated with the combined factors $\alpha_{1}$ PI, HLECS+ lymphocytes, and CXCR4+ lymphocytes $\left(\mathrm{r}^{2}=0.91, \mathrm{p}<0.001\right.$, $\mathrm{n}=30$ ), but not CXCL12. In contrast, in HIV-1 individuals with $>220 \mathrm{CD} 4$ cells/ $\mu \mathrm{l}$, CD4+ lymphocytes were correlated solely with active $\alpha 1$ PI $\left(\mathrm{r}^{2}=0.93, \mathrm{p}<0.0001, \mathrm{n}=\right.$ 26). The monoclonal anti-HIV-1 antibody $3 \mathrm{~F} 5$ present in HIV-1 patient blood bound and inactivated human $\alpha_{1}$ PI. Chimpanzee $\alpha_{1}$ PI differs from human $\alpha_{1}$ PI by a single amino acid which lies within the 3F5-binding epitope. Unlike human $\alpha_{1}$ PI, neither chimpanzee nor macaque

\footnotetext{
* Correspondence: cyb2005@med.cornell.edu
} Weill Cornell Medical College, New York, USA $\alpha_{1}$ PI bound to 3 F5, nor was $\alpha_{1}$ PI depleted following HIV1 challenge, consistent with the normal $\mathrm{CD} 4^{+}$lymphocyte numbers of HIV-1 infected chimpanzees. The presence of IgG- $\alpha_{1}$ PI immune complexes correlated with decreased $\mathrm{CD}_{4}^{+}$lymphocytes in HIV-1 individuals, and $\alpha 1 \mathrm{PI}$ augmentation quadrupled the number of immunocompetent $\mathrm{CD} 4^{+}$lymphocytes with no untoward effects.

\section{Conclusions}

An autoimmune component of HIV-1 disease was identified and was overcome therapeutically. Results identify an achievable vaccine modification with the novel objective to protect against AIDS as opposed to the current objective to protect against HIV-1 infection.

Published: 25 May 2012

doi:10.1186/1742-4690-9-S1-P23

Cite this article as: Bristow et al:: Alpha-1-proteinase inhibitor regulates CD4 lymphocyte levels and is rate limiting in HIV-1 disease. Retrovirology 2012 9(Suppl 1):P23.

Submit your next manuscript to BioMed Central and take full advantage of:

- Convenient online submission

- Thorough peer review

- No space constraints or color figure charges

- Immediate publication on acceptance

- Inclusion in PubMed, CAS, Scopus and Google Scholar

- Research which is freely available for redistribution

Submit your manuscript at www.biomedcentral.com/submit C Biomed Central

\section{Biomed Central}

(c) 2012 Bristow et al; licensee BioMed Central Ltd. This is an Open Access article distributed under the terms of the Creative Commons Attribution License (http://creativecommons.org/licenses/by/2.0), which permits unrestricted use, distribution, and reproduction in any medium, provided the original work is properly cited. 